\title{
When Social Media Doesn't Determine All: The Topics and Narratives of Latvian Political Parties on Facebook During the 2019 European Parliament Elections
} Campaign

Mārtiņš Pričins

University of Latvia (Latvia)

Over the last decade, the implementation of campaigns by political parties and their candidates on social media platforms has become an integral part of political communication. Political communication studies have long indicated that elections are becoming personalized, with more focus on party leaders or individual candidates. But studies on communication by political parties to understand the identity of parties and their potential in communication with voters remain relevant.

The aim of the paper is to analyse the visual election materials of the political parties from Latvia on the social network Facebook during the 2019 European Parliament (EP) election campaign. The research period is two weeks before elections. The subject of the study is election materials on Facebook accounts of the parties representing the national parliament of Latvia. A codebook for analysis has been developed, containing common and specific variables, designed to explore the verbal and visual dimensions.

The results of the study allow us to draw conclusions about the changing success of new populist and traditional parties, as well as to look at the role of Facebook in elections in a little-studied country.

Keywords: European Parliament elections, social networking site Facebook, political communication, political parties in Latvia, narratives. 


\section{POLITICAL COMMUNICATION TRENDS AND THREATS ON SOCIAL MEDIA}

It would be a mistake to believe that the success in elections can only be achieved by a successful campaign on social networks. In the meantime, this is not possible both because of the different usability of the media of citizens and because longterm parties have a strong reputation, experience and other factors that influence both campaign-making and voter perception (Suuronen, 2018). Recent studies have shown that the new or newly established parties are paying more attention to social media than big and "old" parties (Lilleker, Tenscher, and Štětka, 2015). The possible reasons for this trend are the smaller hierarchical structure of the new parties, the involvement of young people and their greater openness to new communication opportunities.

It should be noted that there are two conflicting assumptions in theoretical literature. The smoothing approach involves small parties seeking to compensate for the lack of attention of resources, human resources and traditional media, attracting voter attention with the use of direct channels known in literature as an "avoidance strategy". On the other hand, the normalisation approach means that large-party campaigns with greater financial and human resources are more capable of creating effective communication and mobilising voters online than small or marginal parties (Magin et al., 2016).

Faced with a prolonged decline in party identification, parties need to find new ways to attract voter attention. Political campaign researchers say that traditional media are still considered to be important campaign tools, but the impact of social media on political campaigns worldwide is increasing. Technological developments lead to an increased awareness-raising environment leading to a lack of time for users. That way, the wealth of information creates attention poverty (Zelče, 2018).

Social network sites are Internet platforms with web services that allow individuals, first, to create a public or semi-public profile in a limited system, and secondly to establish a list of other users with whom information can be shared, thirdly, to review and follow information published or interacted in the system. It is essential to introduce clarity in terms of work, since academic literature often understands social media the same as social network sites. However, it should be noted that social media is a much wider media group, including blogs, the online encyclopaedia Wikipedia and other editable sites, online forums, etc.

Platforms such as Facebook and Twitter changed the order for political campaigns and the access of politicians and the public to political information. However, the results of studies carried out over time are often contradictory. This situation is illustrated by two quantitative studies on the use of social media and political participation carried out by Shelley Boulianne, a research researcher at MacEwan University. The study in 2009 showed that Internet usage as a whole has a positive but narrow impact on the various aspects of political engagement. Meanwhile, a repeat study in 2015 showed only the impact of limited use of digital media on political participation. 
The results of political communication studies show that the digital environment socialises young voters in a polarised information environment, which, despite this, can increase their participation in the forthcoming elections. Although researchers point to the impact of limited social networks, recent studies show that if young people actually gain information on policies, this is due directly to social networking sites (Ohme, 2019; Dimitrova and Matthes, 2018). According to Ohme, social networking sites are changing the way they publish political content. Social network sites may have content that are: 1) more relevant, because site algorithm influenced by the choice of previous sources and network of contacts; 2) more diverse, resulting from a large range of different sources of choice free and randomly available; 3) more direct than obtained policy content from offline or non-social online channels, influenced by social approvals, for example, suggestions, reactions, or comments, that way some media content appears on the news tape. This means that the content is more relevant and could affect the user's interpretation, i.e. policy-related thoughts or actions.

\section{NARRATIVES, EUROPEAN IDENTITY AND TRUST}

In addition to the trend of fewer and fewer citizens participating in elections every year in Europe and elsewhere, the European Parliament elections are often marked as second-order elections (Kovar and Kovar, 2012; Auers, 2019), with far fewer voters than national or regional elections. In this case, the ability of political actors to tell meaningful narratives is becoming important.

Narrative expression is not only a basic form of communication, but it is also a way of thinking that shows how social and political meanings are formed. This makes it possible to assess the social positions of the community. From a psychological point of view, the identity of the message is viewed as a stock of knowledge about narrative memories that provide a causal, time-and-subject relationship with a general sense of identity and give the story scheme of life. In the political environment, these stories are used at the level of both individuals and groups/organisations (Sheafer, Shenhav, and Goldstein, 2011).

During election campaigns political leaders are ready to speak about the legacy of history and future development. Existential political position suggests and discuss evaluating experiences in time and space. Therefore, when we hear people's personal stories, we can understand national perceptions from the stories of our nation.

Establishing and accepting a European identity is in the interest of the European Union in order to make it up to date and important for citizens. The German social memory researcher Aleida Assmann believes that Europeans lack self-confidence, mobilising and identity-building forces that prevent the EU from finding a common and united view (Skudra, 2011).

It would therefore be worth looking into the three phases of the development of nations and identities offered by Czech professor Miroslav Hroch. The first phase is the time when groups are searched and formed, when language, culture, 
history and other features are not yet dominated. The second phase is mobilizing around activists and their ideas, where two periods are distinguished, when there is no success, and when an interested audience is found. The third phase is the mass movement phase. As in every process, it may not be with a positive result and has its own reasons. This can be influenced by the interests, role and degree of involvement of activist leaders, by the intensity of communication, by the group's interests, by the creation and support of the enemy's image and by the support of other powers (Skudra, 2011).

Latvia has a large Russian-speaking minority of around 30\% of the population. The fact that a considerable share of the minority are non-citizens further complicates the situation members of this group are often critical of the Latvian government. Thus, some segment of society remains exposed and vulnerable to Russian media propaganda (Bikovs, Bruge, and Spruds, 2017). Latvia's political culture aims to move towards European and Northern European ideas, but the baggage of experience also includes the characteristics of post-Soviet countries. This is reflected in both the low credibility of local and international political organisations/institutions and the high impact of Russian media on Latvia's informative environment.

According to the Eurobarometer 2019, 54\% of citizens of Latvia consider the membership of the EU is a good thing, which is the lowest rate among the Baltic States, 54\%, while Estonia has 74\% and Lithuania 71\%; average in EU27 is 61\%. More than half of citizens (56\%) would like to see the European Parliament play a more important role, far more than in Estonia (34\%), close to the average level between EU countries (54\%), but less than in Lithuania (66\%).

\section{IMPORTANCE OF KNOWLEDGE AND SOCIAL MEDIA USAGE}

The influence of the media depends on the particular platform, content, style, age and cognitive skills of the consumer of the news, as well as the satisfaction he receives from political media. Those who follow the news in any way are more knowledgeable about those peers who do not follow them at all. Likewise, those who follow the news know more about politics than those who do not follow the news (Chaffee and Roser-Renouf, 1986).

People in social media are able to follow, respond to, and share news, but there are a number of important questions about the reliability of communication, the sources of news and the truth that creates contrasting predictions of political reality and concern about the mix of quality and populism. One of today's peculiarities is the fragmentation of information that emanates from communication and socio-political diversification. Audience and media fragmentation, people's selective submissions in accordance with their beliefs and the tendency to reinforce them in such a way that they are likely to contribute to the political and media block polarization. Thus, on the one hand, as a result of the ease of communication, citizens can experience high levels of communication and even efficiency; but, on the other hand, they are rarely able to compile discourses, feelings and suggestions from administrative bodies (Blumler, 2016). 
Recent media literacy data about the inhabitants of Latvia show that online news media and social networking platforms are playing an increasingly important role in shaping Latvia's information environment (Latvijas Fakti, 2017). This is confirmed by the growth indicators of Internet use of the Latvian population. According to the data of the Central Statistical Bureau of Latvia, in the last decade the number of households in the country where the Internet is available has significantly increased (by 21.8\%), and at the end of 2018 it reached $81.6 \%$. The Internet is most often available in households with two children (98.6\%), but least often in one-person households (64.9\%).

Residents of Latvia most often used the Internet to 1) use e-mail (83.8\%); 2) Internet banking (79.4\%); 3) search for information about goods or services $(75.7 \%) ; 4)$ use social networks $(73.5 \%)$. Women use social networks more than men $(78.2 \%$ vs. $68.3 \%$, respectively). The social network usage rate correlates with the age group - the younger the age group, the higher the usage (CSB, 2018).

Similar data are presented in a study commissioned by the National Electronic Mass Media Council (NEPLP), which indicates that social media (YouTube, Facebook, Twitter) is used by $72 \%$ (52\% every day, 69\% at least once a week). The report concludes that the consumption of various information resources and media is closely linked to the age of the respondents: the younger the respondent, the less frequent television, radio and press are used, from 16 to 30 years use social media (98\%), as well as online news media (93\%). According to a pre-election survey, $43 \%$ of people read something about politics on news websites more than three times over the last four weeks (minimum once - 65\%), while $36 \%$ said that read something about politics on online social networks (minimum once - 57\%) (European Parliament, 2019b).

However, it is significant that in general Latvian society trusts Internet resources and social media only $29 \%$ and $9 \%$ of the population, respectively. By comparison, 52\% trust the television, 15\% trust the radio, and 14\% trust the press. In this study, Facebook was mentioned as the eighth most popular medium for information about local events, and 7\% of the population trust the site (Latvijas Fakti, 2018). In addition to the low level of trust in social media, the level of trust in the national parliament is consistently low -only 1\% fully trust it, $18 \%$ rather trust it, but $25 \%$ do not trust it completely (SKDS, 2018).

\section{METHODOLOGY}

16 parties from Latvia participated in the European Parliament elections. For technical reasons, the study included 7 parties that overcame the $5 \%$ barrier in the 2018 national parliament elections and got seats there. Time frame is 2 weeks before elections or 11 May - 25 May 2019. During this period parties on social networking site Facebook posted 531 publications, but total of 196 pre-election materials containing verbal or visual references to the European Parliament elections were recognised as valid for the study. This sample was collected during European Parliament election campaign with web tool provided by Kapusons. 
Three research questions were raised in the work:

1. How and on what topics do political parties communicate during election campaign?

2. What is the role of national and European symbols in party materials?

3. Is there a connection between emotional messages and election results?

In this paper were used content analysis and narrative analysis. The codebook was created and used to identify common and specific variables. Verbal analysis took into account aspects such as the references to the nation or Europe, political or ideological anchors, diversity of topics, representation of Europe, the prevalence of European or national dimension, rational or emotional tone. Visual analysis looked at presence of symbols of party, country, Europe in election materials. The two coders were involved in coding process. The calculated inter-coder reliability is $0.86 \%$.

\section{RESULTS AND FINDINGS}

5 parties entered the European Parliament from Latvia. The winner of the election of the European Parliament in 2019 was the New Unity (former Unity) party. It got much lower result in the elections of the national level in 2018 (see Table 1). Party Alliance Development/For! (A/P!) entered the European Parliament for the first time.

A very unique situation is for Harmony party, which, due to the political situation, was little active in social media, but its leader had only appeared in one electoral material. The leader of the party and former Mayor of Riga Nils Ušakovs announced his candidacy at the time of the EP elections, when campaigning for and against his dismissal was actively organised. While individual candidates and other media continued to make a significant contribution to maintaining his support, the isolation of the leader and the choice almost not to inform their voter about the campaign should be seen as unusual phenomenon.

It should be noted that $33.53 \%$ of the voters in Latvia participated in the elections to the European Parliament, while $54.55 \%$ of the voters participated in the elections to the national parliament in 2018. 
Table 1. Results of 2019 European Parliament elections in Latvia

\begin{tabular}{|c|c|c|c|c|c|}
\hline & Party & $\begin{array}{l}\text { Results } \\
\text { of the EP } \\
\text { elections }\end{array}$ & $\begin{array}{l}\text { Seats in } \\
\text { EP }\end{array}$ & $\begin{array}{l}\text { Results of the national } \\
\text { parliamentary elections } 2018\end{array}$ & $\begin{array}{l}\text { Seats in } \\
\text { national } \\
\text { parliament }\end{array}$ \\
\hline 1 & New Unity (JV) & $26.24 \%$ & 2 & $6.69 \%$ & 8 \\
\hline 2 & Harmony (Saskaņa) & $17.45 \%$ & 2 & $19.8 \%$ & 23 \\
\hline 3 & National Alliance (NA) & $16.4 \%$ & 2 & 11.01 & 13 \\
\hline 4 & $\begin{array}{l}\text { Development/For! } \\
\text { (A/P!) }\end{array}$ & $12.42 \%$ & 1 & $12.04 \%$ & 13 \\
\hline 5 & $\begin{array}{l}\text { Latvia's Russian Union } \\
\text { (LKS) }\end{array}$ & $6.24 \%$ & 1 & $3.2 \%$ & 0 \\
\hline 6 & $\begin{array}{l}\text { Green and Farmers } \\
\text { Union (ZZS) }\end{array}$ & $5.34 \%$ & 0 & $9.91 \%$ & 11 \\
\hline 7 & $\begin{array}{l}\text { Latvia's Regional } \\
\text { Union (LRA) }\end{array}$ & $4.98 \%$ & 0 & $4.14 \%$ & 0 \\
\hline 8 & $\begin{array}{l}\text { New Conservative } \\
\text { Party }(J K P)\end{array}$ & $4.35 \%$ & 0 & $13.59 \%$ & 16 \\
\hline 9 & Progressives & $2.9 \%$ & 0 & $2.61 \%$ & 0 \\
\hline 10 & KPV LV & $0.92 \%$ & 0 & $14.25 \%$ & 16 \\
\hline
\end{tabular}

Source: Own elaboration.

As shown in the Table 2, the overwhelmingly highest number of Facebook posts during campaign was created by New Unity. New Unity, Harmony, National Alliance (NA), Green and Farmers Union (ZZS) can be considered as traditional or "old" parties. Even though ZZS is a party with long history, its Facebook page is only created in 2017. This is the reason for the convincingly lower number of Facebook page followers, which also resulted in the low engagement per post.

The LRA and the JKP should be regarded as relatively new parties, while the party KPV LV was founded only in 2016 and gained 16 seats in national parliament elections in 2018. Meanwhile, Development/For! is a combination of the party and the recently formed movement, joined by a number of known politicians and personalities. Latvia's Russian Union was last elected to the national parliament in 2006, but party get a mandate in each EP elections since Latvia officially joined the European Union in. Highest engagement per post identified the New Conservative Party, but, as indicated below, the party had problems with content-making, as evidenced by and Facebook users' negative reactions to the materials.

The Table 2 shows that qualitative data should also be seen in the context of quantitative data. For these in the following subsections. 
Table 2. Political parties and their activity on Facebook (11 May - 25 May 2019)

\begin{tabular}{l|l|l|l|l|l|l} 
& Party & $\begin{array}{l}\text { Facebook } \\
\text { page } \\
\text { created } \\
\text { (year) }\end{array}$ & $\begin{array}{l}\text { Page } \\
\text { followers } \\
\text { (May 2019) }\end{array}$ & Posts & Engagement & $\begin{array}{l}\text { avg } \\
\text { engagement } \\
\text { per post }\end{array}$ \\
\hline 1 & New Unity (JV) & 2010 & 2774 & 157 & 6501 & 41.4 \\
\hline 2 & Harmony (Saskanga) & 2009 & 5519 & 29 & 1148 & 39.5 \\
\hline 3 & National Alliance (NA) & 2011 & 17087 & 58 & 3926 & 67.7 \\
\hline 4 & $\begin{array}{l}\text { Development/For! } \\
\text { (A/P!) }\end{array}$ & 2018 & 3563 & 91 & 4135 & 54.4 \\
\hline 5 & $\begin{array}{l}\text { Green and Farmers } \\
\text { Union (ZZS) }\end{array}$ & 2017 & 1359 & 86 & 1573 & 18,3 \\
\hline 6 & $\begin{array}{l}\text { New Conservative } \\
\text { Party (JKP) }\end{array}$ & 2014 & 16030 & 87 & 9177 & 105,5 \\
\hline 7 & KPV LV & 2016 & 14231 & 23 & 950 & 41,3 \\
\hline
\end{tabular}

Source: Own elaboration.

\section{NATIONAL $V S$ EUROPEAN DIMENSION}

Most of the parties focused on comparing national and European dimensions (43.9\%). In these entries, European issues were adapted to Latvia's situation or national problems were promised to be addressed at European level. The highest number of these materials had ZZS and Harmony. They were largely linked to welfare and finance issues. Both parties also stand out because they did not have a purely national themes in the election materials.

After falling out of the coalition of the national parliament in 2018, ZZS focused its long-term campaign on regional messages and ensuring their situation with jobs and funding. Some of the party's materials were video messages from local government leaders, whose party has a significant number, or their deputies, who addressed voters with a similar message. Graphic images highlighted the party's known politicians with slogan "European money for regions of Latvia!" or "For strong counties and good jobs!".

The national dimension $(38,5 \%)$ identified the narrative of parties, in which parties expressed their attitudes on an issue and its priority in their programme, and in presenting their list leaders with special adjectives. The party with highest result, New Unity, often included slogan "Personality. Experience. Influence. Powerfully!". Another way for parties to highlight their importance was to form a narrative of leadership. One party defined itself as leaders in polls, others chose the same approach in narrow groups, such as conducting a survey in one of the student events and then declaring that "educated young people choose to vote for us". 
Figure 1. Dimension of election material

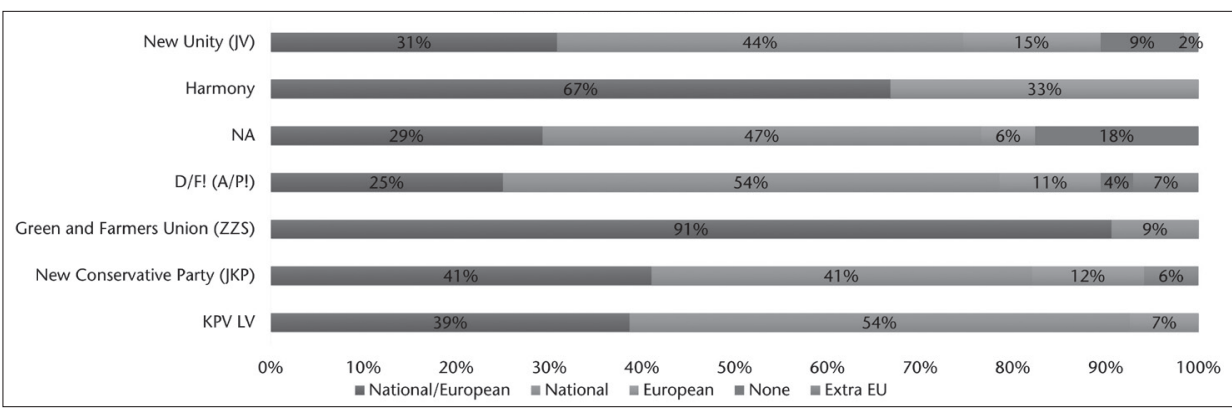

Source: Own elaboration.

Only 9.3\% of the all parties' Facebook posts were linked to Europe alone. These were mainly topics relating to Europe's external borders, different types of contracts, etc. Very rarely (2\%) climate, security and other changes were mentioned. These topics were addressed outside the European context, creating it as a world-class problem where the whole planet should participate.

It is important to note that only every fifth (22\%) Facebook material includes verbal political or ideology reference. In more than half of the entries, this is ZZS (57\%) and New Conservative party (23.5\%), both not elected to the European Parliament. It should be noted that KPV LV and Harmony did not mention such references at all in their Facebook posts, but most other party references were used very rarely. It shows the apoliticality of materials, the inability to propose big political ideas and an attempt to bring voter favorability through other techniques, such as personalization.

\section{DIVERSITY OF TOPICS}

Before elections citizens of Latvia indicated most important themes that should be discussed during electoral campaign. According to Eurobarometer 2019, these include: economy and growth (68\%), combating youth unemployment (46\%), social protection of EU citizens (42\%), immigration (33\%), consumer protection and food safety (32\%), security and defence policy (31\%). Higher expectations than average in EU countries was about economy growth, social protection and security. Significantly lower interest were the issues on immigration (33\% vs 44\% in EU27), environmental challenges (26\% vs 43\%) and fight against terrorism (25\% vs 41\%).

Answering the 1 st research question and comparing the Eurobarometer survey data with the data found in this study, it can be concluded that the parties talked a lot about everything, without significantly highlighting any of the topics. Most often - 10\% of campaign materials - were about production and services, which include agriculture, transport, trade, science, media and other sectors. Surprisingly, the campaign materials only once included the ongoing 
160 greenfield railway infrastructure project Rail Baltica. A major contribution to the promotion of this topic was ZZS, whose campaign was based on the theme of agriculture and providing assistance to the regions. The slogan chosen was simple: "Strong counties in Latvia means strong country". Labor, Europe and values were mentioned in elections materials by $9 \%$ each. Parties talked about development, salaries, Euro funds and taxes, solidarity and national identity, which has always been an important topic for National Alliance and Harmony. Security (6\%), economics (5\%), welfare (5\%) and social (4\%) were mentioned as important issues by Eurobarometer respondents, but parties not enough communicated.

Although some parties in Latvia have shown signs of populism, in general, Europe was negatively represented in the electoral materials in less than 5\% of the cases. One of the rare examples of Europe being represented negatively is ZZS candidate Ringolds Arnītis, who emphasizes that regions of Latvia are becoming even more inactive and empty -Europe takes a lot from Latvia (human and natural resources) so now it is time to take Europe and by which he means money for regions of Latvia. Other example is A/P! and their narrative about EU that Europe is tired, but its old leaders lack courage.

Figure 2. Representation of Europe

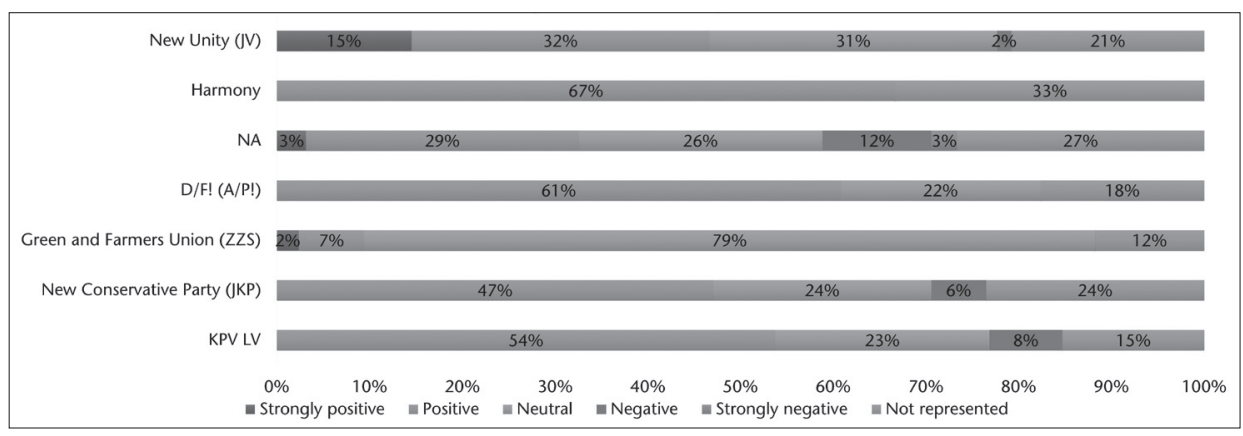




\section{EUROPEAN AND PARTY SYMBOLS, RATIONALISM AND EMOTIONS}

Answering the 2 nd research question, in $76 \%$ cases visual references to party symbols (name, logo, including electoral list number) appear in the materials. The issue of self-identification is important for new democracies. Although previous figures show the ability of parties to link domestic problems with the European agenda in a content-based way, parties mostly choose to symbolise their organisations in the use of visual symbols.

In only $17 \%$ of cases, national visual symbols have been identified in the materials - most often a flag or less commonly known national symbols (Freedom Monument, Oak, National Library and other cultural sites). Only $18,2 \%$ of materials display visual European symbols. Mostly it is the EU flag flying in the background of the candidate. Part of the materials combines the EU flag with the Latvian flag.

Only twice, or in 1\% of cases, either party used official symbol of EU party family membership. One of them was the New Unity, with reference to the European People's Party, the other was a Harmony with a symbol of Party of European Socialists and Frans Timmermans on poster, which was the only time a spitzenkandidat appeared in one of the party materials. Both parties obtained half of the parliamentary mandates available to the country. So it can be summarized that the parties give the symbols only a formal meaning.

Figure 3 contains important results of the analysis of election materials and answer to the 3rd research question. Parties whose emotional messages didn't exceed $40 \%$ of all materials gained at least one mandate. The share of the emotional messages of ZZS, JKP and KPV LV reached at least $2 / 3$, which produced user reactions (see Figure 4 ) but did not give the necessary effect. It should be noted that the three parties did not include neutral content in their messages. The winner of EP elections New Unity distributed its messages almost uniformly.

Figure 3. Message of election content

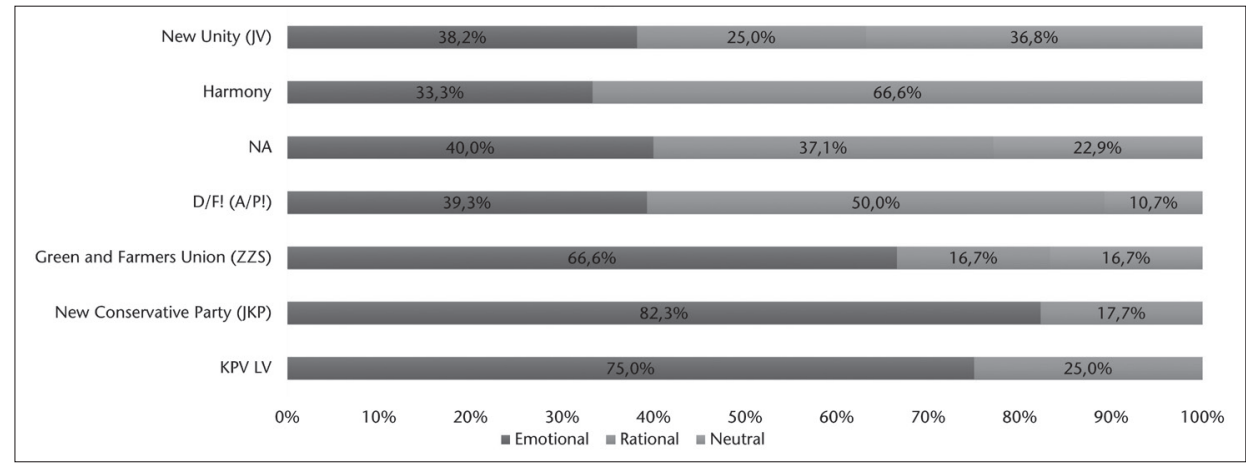


Figure 4 shows the reaction of Facebook users to party materials. By linking this image to Figure 3, connection can be found. The emotional messages create a larger angry (case of JKP) ironic (KPV LV) or sad (ZZS) emotions. There are also high lever or ironic reactions for D/F!, New Unity and National Alliance (over $49 \%$ ), but a relatively high level of favourable reaction should also be noted.

\section{Figure 4. Facebook users' reactions by political party}

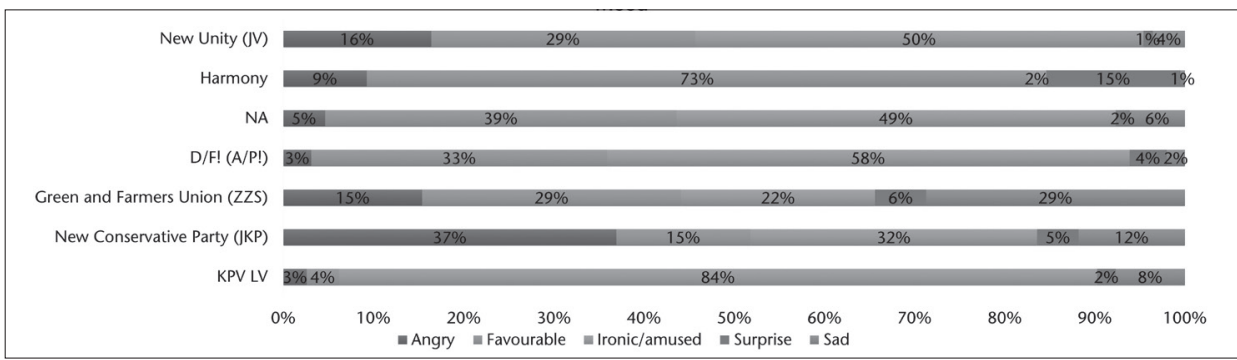

Source: Own elaboration.

Two new parties that successfully overcame the $5 \%$ barrier in the elections to the national parliament in 2018 and were included in the government coalition have failed to obtain mandates in the EP elections. Facebook users' reactions to the New Conservative Party show they had highest angry emotion level from all parties, but users of KPV LV — highest ironic/amused reactions, which is linked to the populist nature of the party and the disappointment of its voters following national parliament elections in 2018, as evidenced by both the party's internal discord, the fall in ratings and the outcome of the EP elections 2019.

\section{CONCLUSIONS}

Political parties from Latvia have been moderately active during the European Parliament elections and its intensity is comparable to that of other countries in the region. The results of the study suggest that Latvian political parties communicate in their materials in a similar manner, but on different topics, creating a fragmented view of Latvia's place in the process of European integration. Parties rarely expressed their position on Europe and its role in the world in their pre-election materials.

"Old" parties based on their content on a "serial-based" campaign mostly resulted in at least one acquired mandate. The exception is the Green and Farmers Union, which included narratives in its materials for the country's regions, but did not benefit.

For those political parties in Latvia that entered the European Parliament, the campaign identified both a broad range of topics and, as mentioned in theoretical part, narratives that provide a causal, time-and-subject relationship with a general sense of identity. From the psychological aspect of the electorate, 
this was particularly important, as the candidates also described, among other things, the advantages and the positive effects that the electorate and the state have on being a member of the European Union.

In this work, a link between party communication and its content, user reaction and election results has been found. The study methodology should be replicated in other studies to ensure consistency of results.

Parties, which dominated on Facebook by emotional messages ( $>40 \%)$, did not get mandates. Despite the increased consumption of the Internet in the country and the increasing involvement of parties in the Facebook campaign, voter turnout in the elections was well below that of the national parliament or municipal elections, which still show the EP as a second-order elections.

By linking the connection between the emotional messages and the outcome of the elections, it can be concluded that voters supported campaigns, where were rational messages with content relevant to both Latvia and the European Union as a whole. According to theoretical literature, traditional media are still considered to be important campaign tool, which is also revealed under this campaign. Latvian political parties often inform about their appearance in the media, and interview fragments are also inserted.

The unique case is the Harmony, which campaigned on Facebook almost inactively compared with other parties, and activity was one of the lowest among all parties. Despite the negative information background surrounding the party in relation to its leader, Nils Ušakovs, it was able to double its number of mandates. This outcome shows that this party is capable of achieving a high result, mainly on the basis of traditional media and, in particular, Russian-speaking media. It shows long-term ethnolinguistic and ethnocultural sympathies of voters even despite the local political context.

This means that parties can still succeed without being so active on social networking sites, but given that online news media and social networking platforms are playing an increasingly important role in shaping Latvia's information environment, the importance and impact of political campaigns in Latvia's digital informative environment can be predicted.

The political environment of Latvia alone and the Baltic region as a whole has been little studied in academic journals, so it would be important to continue researching these countries.

Note: Part of the data is derived during participation in the European Election Monitoring Center. Project was partly funded by the European Parliament (COMM/SUBV/2018/E).

Mārtiņš Pričins (martins.pricins@lu.lv) is an assistant researcher in the Advanced Social and Political Research Institute in the University of Latvia. He is working on doctoral thesis about political communication of parties and their narratives during election campaigns on social media. He is also a lecturer in University of Latvia. 


\section{References}

Auers, Daunis (2019). "The 2019 European Parliament Elections in the Baltic States". Riga: Friedrich Ebert Stiftung. Available at: <http:// library.fes.de/pdf-files/bueros/baltikum/ 15480.pdf >. Accessed 30 March 2020.

Bikovs, Arturs; Bruge, Ilvija, and Spruds, Andris (2017). Russia's Influence and Presence in Latvia. Brussels: New Direction.

Blumler, Jay G. (2016). "The Fourth Age of Political Communication". Politiques de Communication, 6 (1), pp. 19-30.

Boulianne, Shelley (2015). "Social Media Use and Participation: A Meta-Analysis of Current Research". Information, Communication \& Society, 18 (5), pp. 524-538.

Chaffee, Steven H. and Roser-Renouf, Connie (1986). "Involvement and the Consistency of Knowledge, Attitudes, and Behaviors". Communication Research, 13(3), pp. 373-399.

European Parliament (2019a). "Eurobarometer Survey 91.1 of the European Parliament. A Public Opinion Monitoring Study". Available at: <https://www.europarl.europa.eu/ at-your-service/files/be-heard/eurobarometer/ 2019/closer-to-the-citizens-closer-to-theballot/report/en-eurobarometer-2019.pdf>. Accessed 30 March 2020.

-. (2019b). "Flash Eurobarometer 4021. Emotions and Political Engagement Towards the EU". Available at: <https://www.europarl.europa.eu/at-your-service/files/be-heard/ eurobarometer/2019/emotions-and-politicalengagement-towards-the-eu/national-factsheets/lv-en-flash-2019.pdf>. Accessed 30 March 2020.

Dimitrova, Daniela and Matthes, Jörg (2018). "Social Media in Political Campaigning Around the World: Theoretical and Methodological Challenges". Journalism \& Mass Communication Quarterly, 95(2), pp. 333-342.

Kovar, Jan and Kovar, Kamil (2012). "National of European? EP Election Campaign Themes in the News Media". European Electoral Studies, 7(1), pp. 30-41.
Latvijas Fakti (2017). "Latvijas iedzīvotāju medijpratība". Available at: <https://www. $\mathrm{km}$.gov.lv/uploads/ckeditor/files/mediju_ politika/petijumi/Medijpratiba_petijuma $\% 20$ rezultati_Latvijas\%20Fakti_18_07_2017.pdf>. Accessed 30 March 2020.

-. (2018). "Pētījums par Latvijas iedzīvotāju interesēm, dienaskārtību un uzticēšanos medijiem". Available at: <https:// neplpadome.lv/lv/assets/documents/ Petijumi/Mediju_lieto\% C5\%A 1 ana atskaite_08.2018_\%20(002).pdf>. Accessed 30 March 2020.

Lilleker, Darren G.; Tenscher, Jens, and Štětka, Václav (2015). "Towards Hypermedia Campaigning? Perceptions of New Media's Importance for Campaigning by Party Strategists in Comparative Perspective". Information, Communication \& Society, 18(7), pp. 747-765.

Magin, Melanie; Podschuweit, Nicole; Haßler, Jörg, and Russmann, Uta (2016). "Campaigning in the Fourth Age of Political Communication. A Multi-method Study on the Use of Facebook by German and Austrian Parties in the 2013 National Election Campaigns". Information, Communication \& Society, 20(11), pp. 1698-1719.

Ohme, Jakob (2019). "When Digital Natives Enter the Electorate: Political Social Media Use Among First-time Voters and Its Effects on Campaign Participation". Journal of Information Technology \& Politics, 16(2), pp. 1-18.

Perloff, Richard M. (2014). The Dynamics of Political Communication: Media and Politics in a Digital Age. New York and London: Routledge.

Sheafer, Tamir; Shenhav, Shaul R., and Goldstein, Kenneth (2011). "Voting for Our Story: A Narrative Model of Electoral Choice in Multiparty Systems". Comparative Political Studies, 44(3), pp. 313-338.

SPPI (2011). Nacionālā identitāte: politiskās identitātes un politiskā kultūra. Rīga: LU SPPI. Available at: <https://www.szf.lu.lv/fileadmin/ user_upload/szf_faili/Petnieciba/sppi/mediji/ 
NI_Politiska_identitate_politiska_kultura.pdf>. Accessed 30 March 2020.

Suuronen, Aleksi (2018). Political Competition and Social Media: Can Facebook Change the Status Quo of Finnish Politics? Tampere: University of Tampere. Available at: <https://trepo.tuni.fi/ bitstream/handle/10024/103373/1526296871. pdf?sequence $=1$ \&isAllowed $=y>$. Accessed 30 March 2020.

Zelče, Vita (ed.) (2018). Latvijas mediju vide. Rīga: LU Akadēmiskais apgāds. 